\title{
LUBUK LARANGAN: DINAMIKA PENGETAHUAN LOKAL MASYARAKAT DALAM PENGELOLAAN SUMBER DAYA PERIKANAN PERAIRAN SUNGAI DI KABUPATEN LIMA PULUH KOTA
}

\section{Lubuk Larangan : Local Community Knowledge Dynamics of Inland Fisheries Resources Management in Lima Puluh Kota Regency}

\author{
*Christina Yuliaty dan Fatriyandi Nur Priyatna \\ Balai Besar Penelitian Sosial Ekonomi Kelautan dan Perikanan \\ Gedung Balitbang Kp I Lt. 4 \\ Jalan Pasir Putih Nomor 1 Ancol Timur, Jakarta Utara \\ Telp: (021) 64711583 Fax: 64700924 \\ "email: yuliaty.christina@gmail.com \\ Diterima 4 April 2014 - Disetujui 6 Juni 2014
}

\begin{abstract}
ABSTRAK
Tulisan ini menggambarkan bagaimana masyarakat lokal memiliki pengetahuan dalam pengelolaan sumber daya perikanan perairan sungai. Pengetahuan ini berwujud nilai kearifan lokal, falsafah hidup, religi dan norma-norma hukum lokal yang digunakan dalam pemanfaatan sumber daya. Penelitian dilaksanakan pada tahun 2012 pada masyarakat Minang Nagari Sialang Kecamatan Kapur IX, Kabupaten Lima Puluh Kota Sumatera Barat yang menetap di daerah aliran sungai Batang Kapur. Penelitian dilakukan menggunakan pendekatan kualitatif. Pengambilan data dilakukan dengan cara observasi langsung, wawancara mendalam dan diskusi kelompok terarah. Analisis deskriptif kualitatif dilakukan melalui pendekatan studi kasus terkait dengan pemanfaatan dan pendayagunaan sumber daya perikanan perairan sungai secara lokal. Hasil penelitian menunjukkan bahwa Lubuk larangan tidak hanya sebuah praktek pemanfaatan dan pendayagunaan sumber daya ikan tetapi didalamnya terdapat aturan, mekanisme distribusi hak dan organisasi adat. Sesuai dengan sifatnya yang dinamis, maka pengetahuan pengelolaan lubuk larangan pun mengalami perubahan. Nilai Islam dan politik pemerintahan menjadi pendorong terjadinya perubahan dalam pengelolaan Lubuk Larangan.
\end{abstract}

Kata Kunci: pengetahuan lokal, pengelolaan sumber daya, Lubuk Larangan

\begin{abstract}
This paper aimed to describe how the local community has knowledge in the resources management of inland fisheries. This knowledge consistss value of local wisdom, philosophy of life, religion and local legal norms used in resource utilization. This study was conducted in 2012 at Nagari Sialang, Kapur IX, Lima Puluh Kota Regency, West Sumatera the Minang community who settled in the Batang Kapur watershed as the unit of analysis. This study used anthropological approach. Data were collected by direct observation, in-depth interview and focus group discussions. Analysis of qualitative descriptive approach used a case study regarding the used and utilization of fish resources in the local river waters. The results showed that 'Lubuk Larangan' is not only resaurce used and utilization practices but also a set of rule, rights distribution mechanisms and customs. Knowledge regarding management of 'Lubuk Larangan' is also changing dinamically. Islamic values and political governance become driving forces for the management of Lubuk Larangan changes.
\end{abstract}

Keywords: local knowledge, resource management, Lubuk Larangan 


\section{PENDAHULUAN}

Pengetahuan lokal menjadi akhir-akhir ini menjadi wacana yang ramai diperbincangkan karena dianggap sebagai bagian penting dalam program pembangunan dalam upaya pengelolaan sumber daya. Pengetahuan lokal yang bersumber dari kebudayaan masyarakat dianggap memberi banyak solusi dalam pembangunan karena merupakan hasil 'belajar' dari masyarakat lokal dalam mesikapi dinamika perubahan lingkungan mereka (Lubis, 2005). Pengetahuan lokal yang ada memberikan indikasi bahwa masyarakat lokal berpartisipasi dalam melakukan kontrol dalam pemanfaatan sumber daya yang ada karena merekalah yang memiliki kepentingan terhadap sumber daya tersebut. Kearifan lokal dalam pengelolaan sumber daya perikanan umumnya muncul dalam bentuk pantangan atau larangan. Keduanya memliki landasan filosofis yang berbeda. Pantangan memiliki corak religio-magis sementara larangan terkait dengan aturan hukum adat (Lubis, 2005). Meskipun memiliki landasan yang berbeda. Keduanya berpihak pada keseimbangan alam dan jaminan kehidupan bagi anggota masyarakatnya. Pengetahuan lokal tersebut sudah menyatu dengan sistem kepercayaan, norma dan budaya diekspresikan dalam tradisi dan mitos.

Upaya masyarakat melakukan kontrol dalam pemanfaatan sumber daya sejalan dengan prinsip Perlindungan dan Pengelolaan Lingkungan Hidup yang menurut UU No. 23 Tahun 1997 Jo UU No.32 Tahun 2009 disebutkan sebagai upaya sistematis untuk melestarikan fungsi lingkungan hidup dan mencegah terjadinya pencemaran dan/ atau kerusakan lingkungan hidup yang meliputi perencanaan, pemanfaatan, pengendalian, pemeliharaan, pengawasan dan penegakan hukum. Dalam Undang-undang ini disebutkan bahwa salah satu azas dalam upaya perlindungan dan pengelolaan lingkungan hidup berdasarkan UU No. 32 Tahun 2009 adalah kearifan lokal. Solihin \& Satria (2007) menyatakan bahwa solusi untuk mengatasi permasalahan terkait pengelolaan sumber daya adalah dengan pemberian hak pengelolaan kepada masyarakat lokal sesuai dengan keadaan sosial, ekonomi, politik, budaya, dan karakteristik sumber daya di sekitarnya.

Kondisi sosial masyarakat setempatlah yang membentuk pola pengelolaan sumber daya yang ada oleh karena itu sangatlah penting untuk memperhatikan faktor masyarakat dalam memanfaatkan dan mendayagunakan sumber daya yang ada (Priyatna, 2003). Masyarakat lokal memiliki kebudayaan sebagai pedoman hidup mereka dalam menghadapi lingkungan di mana mereka hidup.

Lubuk larangan merupakan salah satu bentuk kearifan yang berkembang pada masyarakat lokal dalam memanfaatkan sumber daya perikanan perairan sungai di Sumatera Barat. Lubuk larangan tersebut merupakan perwujudan prinsip konservasi yang dilakukan oleh masyarakat terhadap sumber daya perikanan perairan sungai.

Tulisan ini bertujuan, pertama; untuk menggambarkan pengetahuan lokal masyarakat Minang dalam pengelolaan sumber daya perikanan di sungai yang dinamakan Lubuk Larangan. Kedua, mengkaji dinamika pengetahuan yang terjadi.

Tulisan ini mencoba melihat dinamika pengetahuan pengelolaan sumber daya perikanan perairan sungai dalam hal ini konservasi melalui kajian Antropologi. Antropologi dapat berperan serta banyak dalam mengkaji masalah-masalah pembangunan yang tidak hanya sekedar melihat pembangunan dari sisi ekonomi melainkan dari semua sektor termasuk sosial, politik, agama dan budaya (Kasniyah, 2005). Menurut Alam (1998), antropologi dapat memberikan sumbangsih dengan mengungkapkan kodrat setiap kebudayaan yang bersifat dinamis, cair dan hibrid dengan menghindari serta mengkritik representasi budaya yang bersifat esensialis dan statis. Atas dasar pernyataan di atas maka perlu melihat bagaimana masyarakat lokal memformulasikan kearifan lokal agar sesuai konteks saat ini tanpa meninggalkan esensi dasar dalam pengelolaan sumber daya.

Antropologi adalah studi tentang manusia dalam memahami dunianya. Agar dapat memahami suatu masyarakat kita harus berusaha memahami bagaimana mereka, diri mereka dan bagaimana mereka merepresentasikan dunianya. Ini yang membedakan Antropologi dengan ilmu-ilmu sosial lainnya (Lowe, 2006). Untuk itulah pentingnya meneliti pengelolaan sumber daya perikanan perairan sungai dalam hal ini konservasi melalui kajian Antropologi. Tulisan ini menekankan pada dinamika pengetahuan pengelolaan sumberdaya yang dinamakan Lubuk Larangan, bukan pada organisasi adat Lubuk Larangan itu sendiri.

\section{Metode Penelitian}

Penelitian ini menggunakan pendekatan deskriptif kualitatif. Tan (1994) menuliskan bahwa 
penelitian yang bersifat deskriptif bertujuan menggambarkan secara tepat sifat-sifat suatu individu-individu, keadaan, gejala, atau untuk menentukan frekuensi atau persebaran. Moleong (2007) menyebutkan bahwa penelitian kualitatif adalah penelitian yang bermaksud untuk memahami fenomena tentang apa yang dialami oleh subjek penelitian, misalnya prilaku, persepsi, motivasi, tindakan dan lain-lain secara holistik dan dengan cara deskripsi dalam bentuk kata- kata dan bahasa, pada suatu konteks khusus dan alamiah dengan memanfaatkan berbagai metode alamiah. Dalam tulisan ini pengetahuan lokal dilihat sebagai produk kebudayaan yang akan digunakan sebagai: (1) alat metodologi untuk memahami corak sistem sosial yang dipunyai oleh masyarakat; (2) alat untuk dapat mengarahkan dan menambah kekayaan budaya warga masyarakat; dan (3) alat untuk membantu kita lebih memahami jika ada perubahan di satu bagian maka akan menimbulkan perubahan dalam berbagai pranata yang dapat merugikan masyarakat tersebut karena tidak sesuai dengan kondisi lingkungan hidupnya (Syahyuti, 2010).

\section{Waktu dan Tempat Penelitian}

Penelitian dilakukan pada Lubuk Larangan Anak Nagari Pantai Lok Na pada bulan April 2012. Lubuk Larangan ini berada pada Batang (Sungai) Kapur yang secara administratif berada di Nagari Sialang, kecamatan Kapur IX, Kabupaten Lima Puluh Kota, Provinsi Sumatera Barat. Ada 74 Lubuk Larangan di Kabupaten Lima Puluh Kota dan baru 11 diantaranya yang sudah diatur dalam Peraturan Nagari (PERNAG) termasuk di dalamnya Lubuk larangan Anak Nagari.

Lubuk Larangan Anak Nagari memiliki nama lain yaitu Lubuk Larangan Batu Pelana. Saat ini Lubuk Larangan ini terkenal dengan nama Lubuk Larangan Pantai Lokna, nama yang diberikan oleh seorang peneliti asal Perancis yang dahulu pernah meneliti mengenai Lubuk Larangan ini namun meninggal dunia sebelum selesai tugas penelitiannya. Ada 3 Lubuk Larangan di Nagari Sialang, yaitu Lubuk Larangan Anak Nagari, yang kedua adalah Lubuk Larangan Tanjung Gadang Sakato dan Lubuk Larangan Mudik Mudo. Lubuk Larangan Anak Nagari dipilih sebagai kasus kajian dalam tulisan ini. Lubuk larangan ini memiliki panjang $700 \mathrm{~m}$ dan lebar $30 \mathrm{~m}$ yang memanjang mulai dari Ampang Gadang 1 sampai ke Pantai Lokna dan berakhir di Ngungun.

\section{Metode Pengumpulan Data}

Data yang digunakan adalah data primer yang diperoleh melalui penelitian lapangan (field research) dalam bentuk observasi lapangan, wawancara mendalam dan diskusi kelompok terarah (Focus Group Discussion). Observasi lapangan dilakukan untuk melihat secara langsung dan mencatat kondisi lubuk larangan, pembagian zona lubuk dan aktivitas masyarakat di sekitar lubuk larangan. Wawancara mendalam dilakukan dengan informan kunci (key informant) untuk memperoleh data mengenai sejarah, aturan lubuk larangan, pelaksanaan penegakan aturan serta pengawasannya. Kami juga melaksanakan diskusi kelompok terarah yang mempertemukan kesemua informan dengan tujuan mendapat informasi secara utuh mengenai lubuk larangan.

Penentuan informan dilakukan secara purposif dimana informan ditentukan karena alasan khusus atas dasar kriteria tertentu. Informan kunci (key informant) adalah yang dianggap mampu menjelaskan mengenai sejarah, aturan dan pelaksanaan Lubuk larangan. Mereka adalah tokoh masyarakat seperti tetua adat yang didalamnya adalah ninik mamak, wali nagari (kepala desa) dan ketua POKMASWAS (Kelompok Masyarakat Pengawas). Informan kunci dalam penelitian ini dijelaskan dalam Tabel 1.

Sementara data sekunder diperoleh dari kepustakaan (library research) terkait dengan hasil penelitian sebelumnya baik mengenai kearifan lokal, pengetahuan lokal dan pengelolaan sumber daya.

\section{Analisis dan Interpretasi}

Metode analisis yang digunakan adalah analisis deskriptif, meliputi proses editing data, kategorisasi dan penafsiran data (Moleong, 2006). Tulisan ini mencoba melihat pengetahuan lokal sebagai bagian dari kebudayaan yang sifatnya dinamis. Kedinamisannya dipengaruhi beberapa faktor, termasuk kekuasaan dan kepentingan para pelaku. Implikasinya adalah adanya dinamika dalam kelembagaan pengelolaan sumber daya perikanan Lubuk Larangan.

Sebelum melangkah lebih jauh, ada baiknya kita membatasi dahulu pengertian pengetahuan lokal tentunya dalam konteks pengelolaan sumber daya. Pengetahuan lokal adalah pengetahuan yang dimiliki oleh masyarakat melalui pengalaman hidupnya dalam berinteraksi dengan manusia, 
Tabel 1. Metode yang Digunakan, Status Informan dan Jenis Informasi. Tabel 1. Methode Used, Type of Informant, and Type of Information.

\begin{tabular}{|c|c|c|}
\hline $\begin{array}{l}\text { Metode yang Digunakan } \\
\text { Informan / Method Used }\end{array}$ & $\begin{array}{l}\text { Status Informan I } \\
\text { Status of Informant }\end{array}$ & $\begin{array}{l}\text { Jenis Informasi I } \\
\text { Type of Information }\end{array}$ \\
\hline \multirow[t]{3}{*}{ Purposive Sampling } & Tetua Adat/Elders & $\begin{array}{l}\text { Sejarah dan latar belakang } \\
\text { pengelolaan sumber daya / Historyand } \\
\text { background of resource management }\end{array}$ \\
\hline & $\begin{array}{l}\text { Wali Nagari( Kepala Desa)/ } \\
\text { Chief of village }\end{array}$ & $\begin{array}{l}\text { Sejarah desa dan peran serta } \\
\text { pemerintah dalam pengelolaan } \\
\text { sumber daya/ The history of the } \\
\text { village and the role of government in } \\
\text { resource management }\end{array}$ \\
\hline & $\begin{array}{l}\text { Ketua POKMASWAS / } \\
\text { Head of POKMASWAS }\end{array}$ & $\begin{array}{l}\text { Pelaksanaan pengawasan pada } \\
\text { kawasan lubuk larangan/Supervision } \\
\text { in Lubuk Larangan peran sertanya } \\
\text { dalam pengelolaan sumber daya dan } \\
\text { pembentukan peraturan desa(nagari)/ } \\
\text { Participation in resources } \\
\text { management and the formation of } \\
\text { village regulation }\end{array}$ \\
\hline
\end{tabular}

sumber daya alam dan benda-benda yang ada di sekitarnya di suatu wilayah tertentu dari generasi ke generasi. Teknologi pembuatan kapal pinisi, Awig-Awig, Sasi, termasuk pada pengetahuan lokal.

Pengetahuan lokal masyarakat merupakan salah satu faktor penting dalam pengelolaan sumberdaya alam terutama dalam menunjang keberlanjutan suatu ekosistem. Namun sayangnya, pengetahuan lokal ini seringkali terabaikan oleh pengetahuan ilmiah dan pranata sosial hasil ciptaan para pengambil kebijakan (Winarto \& Choesin, 2001). Di sisi lain, pengetahuan lokal juga mengalami perubahan yang disebabkan perubahan sumberdaya secara fisik maupun perubahan sosial, politik, agama dan budaya.

\section{HASIL DAN PEMBAHASAN}

Sumber daya perairan sungai merupakan salah satu tipologi sumber daya perairan umum daratan. Perairan umum adalah suatu genangan air yang relatif luas yang dimiliki dan dikuasai negara serta dimanfaatkan untuk kepentingan dan kesejahteraan masyarakat, baik sebagai mata pencaharian, sumber air bersih, transportasi. Luas perairan umum di Indonesia sendiri sekitar 55 juta ha (Maskur, 2002). Perairan umum meliputi sungai, danau, rawa, saluran irigasi teknis, dan waduk.

Wilayah Propinsi Sumatera Barat memiliki luas perairan umum daratan 64.200 ha yang terdiri dari danau, sungai, telaga, dan rawa yang tersebat di 19 Kabupaten/kota. (Anonimous, 2012). Hal ini memperlihatkan sumber daya perikanan, terutama perikanan perairan umum di wilayah ini memiliki potensi sangat besar. Sumber daya perikanan perairan umum daratan merupakan suatu sumber daya alam yang bersifat terbuka (open access) dan milik umum (common property). Hal ini dapat membuka peluang terjadinya eksploitasi berlebih sehingga sumber daya alam tersebut harus dikelola secara bijak. Salah satu bentuk pengelolaan sumber daya sungai secara arif dan bijak adalah Lubuk Larangan yang dilakukan Masyarakat Minang di Sumatera Barat.

"Alam Takambang menjadi Guru", pepatah inilah yang mendasari kearifan lokal masyarakat Minang di Nagari Ikan Banyak, Sumatera Barat dalam pengelolaan sumber daya ikan di sepanjang Batang (Sungai) Sinamar. Pepatah tersebut memiliki makna alam yang mengajarkan bagaimana manusia seharusnya berprilaku dan bagaimana manusia seharusnya memperlakukan alam yang sudah menyediakan sumber kehidupan bagi manusia.

Pengetahuan lokal yang kemudian terbentuk sebagai hasil dari pemaknaan filosofi hidup tersebut adalah berupa kelembagan pengelolaan sumber daya perikanan. Kelembagaan pengelolaan sumber daya perikanan tersebut dinamakan Lubuk Larangan. Lubuk Larangan adalah model pengelolaan perikanan yang berbasiskan 
masyarakat dengan cara melakukan penutupan sementara suatu kawasan penangkapan ikan di perairan umum daratan, khususnya daerah aliran sungai dalam kurun waktu tertentu. Lubuk Larangan ditandai oleh perbedaan kecepatan aliran sungai. Wilayah yang relatif tenang aliran sungainya ditetapkan sebagai wilayah lubuk larangan, karena umumnya pada daerah yang tenang ikan berkembang biak (Suhana, 2009).

LubukLarangan terdiri daridua kata yaitu lubuk dan larangan. Lubuk sendiri bagian yang dalam dari sebuah sungai, dimana umumnya menjadi tempat berkembangbiaknya ikan sementara larangan adalah aturan yang melarang suatu perbuatan. Jadi artinya lubuk larangan adalah suatu areal dari sungai yang secara alami merupakan tempat bibit ikan ikan atau biota perairan lainnya, di areal tersebut merupakan areal terlarang untuk diambil hasil ikan dan biota lainnya dalam jangka waktu tertentu. Areal ini dikelola oleh masyarakat melalui peraturan nagari.

Pemanfaatan ikan pada lubuk larangan ditujukan untuk pembangunan mesjid dan pembiayaan kegiatan nagari. Masyarakat atau warga nagari hanya dapat melakukan penangkapan ikan di zona pemanfaatan yang terletak di luar zona inti. Masyarakat dapat melakukan penangkapan ikan di zona pemanfaatan saat dilakukan panen bersama atau disebut 'buka lubuk'. Jenis ikan yang terdapat di Lubuk Larangan adalah jenis asli ikan sungai (ikan lokal) yang banyak terdapat di Kabupaten Limapuluh Kota yaitu jenis ikan Kapiek (Puntius schwanefeldi), Ikan Salimang, Ikan Garing (Tor tambroides), Ikan Sibahan, Ikan Baung, Ikan Barau, Ikan Paweh, Ikan Mas, dan Ikan Nila.

Lubuk Larangan memiliki 3 fungsi, yaitu ekologi, ekonomi dan sosial budaya. Fungsi ekologis. Ekologis adalah melindungi keberadaaan jenis ikan lokal, menjadi lokasi penijahan ikan, menjaga kebersihan lingkungan sungai. Secara ekonomi berfungsi membuka lapangan pekerjaan saat lubuk larangan menjadi sarana rekreasi dan menjadi sumber penghasilan tambahan saat lubuk larangan dibuka, sumber dana bagi pembangunan desa, menjadi sumber ketahanan pangan bagi masyarakat. Secara sosial budaya, lubuk larangan berfungsi melestarikan kearifan lokal yang berasal dari nenek moyang mereka, kelestarian lubuk larangan juga ikut serta melestarikan kelembagaan adat, menjadi sarana untuk meningkatkan rasa tanggung terhadap kelestarian sumber daya (Yuliaty et al., 2012).

Lubuk larangan merupakan contoh praktek konservasi yang dilandaskan pada pengetahuan lokal masyarakat terhadap lingkungannya. Masyarakat (penduduk lokal) mempunyai kapasitas pengetahuan untuk memanfaatkan sumber daya alam, hal ini secara tidak sengaja telah memberikan konsekuensiterhadap upaya konservasi(Tambunan, 2008). Prinsip konservasi merupakan usaha-usaha yang secara sadar dilakukan oleh masyarakat untuk menjaga kelestarian sumber daya yang mereka miliki untuk jangka waktu yang tidak terbatas. Ini bertujuan sumber daya dapat bertahan terhadap perubahan konteks sosial, ekonomi, politik, agama dan teknologi modern (Tambunan, 2008).

Pengetahuan lokal dalam pengelolaan sumber daya perairan sungai yang dinamakan Lubuk Larangan merupakan bukti bagaimana masyarakat lokal memahami diri mereka, kebutuhan mereka terhadap sumber daya berdasarkan pengalaman yang mereka lalui. Pada dasarnya kebudayaan adalah hasil kontruksi sosial yang 'diciptakan' sebagai hasil interpretasi dan pengalaman (Lowe, 2006). Lubuk Larangan tidak hanya sebuah praktek pengelolaan sumber daya tetapi harus dilihat sebagai aturan (buka tutup lubuk), mekanisme distribusi hak dan organisasi adat yang mengatur mekanisme pengawasan dan pemberian sanksi yang dalam perjalanannya mengalami dinamika.

\section{Lubuk Larangan Sebagai Aturan}

Aturan dalam Lubuk Larangan mengatur bagaimana masyarakat memperlakukan alamnya, sumber daya yang menjadi sumber penghidupan mereka. Aturan ini berisi pertama tentang wilayah mana dari sungai yang menjadi lubuk larangan. Kedua, pembagian zona dalam lubuk larangan, mana yang menjadi zona inti, pemanfaatan maupun zona penyangga. Ketiga, sanksi yang diberikan bagi pelanggar, baik berupa sanksi sosial maupun sanksi ekonomi atau denda. Pengelolaan Lubuk Larangan Anak Nagari merupakan hasil kesepakatan atau keputusan bersama dari 
Kerapatan Adat Nagari (KAN), Wali Nagari ${ }^{1}$, tokoh pemuda dan tokoh agama. Kerapatan adat Nagari sendiri adalah lembaga permusyawaratan nagari.

Lubuk larangan Anak Nagari hanya membagi wilayah perairan menjadi dua zona, yaitu zona inti dan zona produktif (pemanfaatan). Hal ini sedikit berbeda dengan Peraturan Pemerintah No. 60 Tahun 2007 tentang Konservasi Sumber Daya Ikan yang membagi zona konservasi menjadi tiga, yaitu zona inti, zona penyangga dan zona zona pemanfaatan. Zona inti di dalam lubuk larangan berfungsi sebagai zona konservasi, kawasan khusus dilarangnya aktivitas penangkapan ikan yang berada di Ngungun dengan panjang $100 \mathrm{~m}$ dan lebar $30 \mathrm{~m}$. Zona ini merupakan zona perlindungan dan pelestarian sumber daya perikanan yang dikhususkan bagi perkembangbiakan ikan sehingga tidak boleh dimanfaatkan. Sementara zona produktif yang dapat dimanfaatkan oleh masyarakat (zona pemanfaatan) yang meliputi Ampang Gadang I, Pantai Lokna, Lubuk Jao dan Like Lunguo dengan panjang $600 \mathrm{~m}$ dan lebar $30 \mathrm{~m}$. Zona ini dapat dimanfaatkan sesuai dengan peruntukkannya yang sudah diatur di dalam Peraturan Nagari (PERNAG).

Awalnya, pengikatan wilayah larangan pada lubuk dilakukan melalui proses pemberian mantera atau yang disebut dengan "uduh". Uduh berfungsi sebagai mantra yang bertujuan untuk memagari lubuk sehingga tidak ada pencurian. Uduh sendiri berbentuk semacam do'a yang menurut sejarahnya dipanjatkan pemuka agama. Masyarakat yang melanggar aturan lubuk larangan terkena dampaknya seperti sakit bahkan kematian. Lubuk larangan dapat ditutup dan dibuka untuk dimanfaatkan ikannya oleh masyarakat dengan do'a-do'a dari salah satu pemuka agama tersebut. Penggunaan uduh di wilayah lubuk larangan memiliki fungsi yaitu untuk mengikat ikan supaya tidak berpindah tempat dan untuk menjaga keamanan lubuk dari pencurian dari nagari tetangga.

\section{“ di kecamatan ini pertama kali adanya lubuk larangan....ini lubuk larangan kami tradisional, menggunakan uduh, jadi seperti dipagari oleh ilmu magis. Jadi ikan tidak bisa keluar. Yang mendoakan adalah orang pintar, juru kuncinya"}

Pengunduhan dinilai efektif dalam pelaksanaan lubuk larangan. Pengunduhan ini membuktikan bahwa kearifan lokal dalam pengelolaan sumber daya memang umumnya dikemas dalam terminologi pantangan yang menunjukkan corak religius-magis dan larangan yang berbentuk aturan hukum adat, yang meskipun memiliki landasan yang berbeda namun keduanya memberi efek positif bagi konservasi sumber daya (Lubis, 2005).

Masyarakat percaya ikan di dalam lubuk larangan adalah "ikan yang sudah mempunyai mistik", sehingga tidak akan bisa ditangkap, tulah yang akan menimpa orang yang mengambil ikan ataupun memanfaatkan sumber daya di lokasi lubuk larangan sangat efektif dan fungsional dalam membatasi perilaku warga. Beberapa pantangan yang terdapat di Lubuk Larangan Anak Nagari adalah larangan mengambil ikan bahkan tidak diperbolehkan memegang ikan dan mengekstraksi segala macam sumber daya yang berada di zona inti, pantang mandi siang hari di zona inti yang dapat menyebabkan pelaku menjadi 'masuk angin', larangan mengambil ikan di zona pemanfaatan kecuali pada hari tertentu sesuai hasil kesepakatan bersama, larangan mengganggu ikan, serta pantang berbicara dan berprilaku yang tidak baik. Keberadaan mitos yang terkait dengan lubuk larangan di tengah masyarakat ikut menjamin keberlanjutan keberadaan dan pengelolaan lubuk larangan. Hal yang diperbolehkan di wilayah lubuk larangan adalah kegiatan memberi pakan ikan, berwisata (berenang), mandi, mencuci pakaian dan memanfaatkannya sebagai jalur transportasi.

Pelanggaran terhadap pantangan dan larangan terhadap aturan lubuk larangan dapat menimbulkan akibat dari sekedar kembung, demam, disorientasi yang berakibat oknum yang melanggar datang terus menerus ke lubuk, hingga dipercaya dapat menimbulkan kematian.

Peng'uduh'an, mistifikasi ikan yang hidup dalam lubuk, takhyul yang menyertai keberadaan lubuk larangan merupakan satu kesatuan dalam pengetahuan masyarakat lokal mengenai Lubuk Larangan. Kesemuanya menjadi acuan dalam memperlakukan sumber daya yang mereka miliki, dalam hal ini sumber daya perikanan perairan sungai. Menurut Syahyuti (2010), dalam Antropologi, kebudayaan adalah keterkaitan pola pikir, prilaku dan artefak pada suatu kelompok etnik tertentu. Pola pikir termasuk di dalamnya falsafah hingga takhyul menjadi pedoman prilaku. Ketiganya merupakan kesatuan sehingga tidak bisa dilepaskan satu dengan yang lainnya. 


\section{Lubuk Larangan Sebagai Mekanisme Distribusi Hak}

Biasanya Lubuk Larangan ini dibuka atau buka lubuk diadakan setelah panen hasil kebun ( gambir, kakao, karet, dan kelapa sawit), menjelang puasa, atau setelah lebaran sesuai hasil kesepakatan awal saat musyawarah menentukan pelaksanaan buka lubuk. Masa buka Lubuk bisa mencapai satu minggu lamanya.

Berdasarkan Peraturan Nagari (PERNAG) Sialang No. 02 Tahun 2011, Distribusi penerima manfaat hasil panen untuk Lubuk Larangan Anak Nagari atau Pantai Lokna, sebagai berikut :

a. Kas Pemuda Nagari dan Pemuda Jorong sebesar $50 \%$

b. Operasional Pokmaswas sebesar $20 \%$

c. Pemberdayaan Adat sebesar $10 \%$

d. Pemerintah Adat Nagari Sialang 10\%

e. Lembaga Swadaya Nagari $10 \%$

Namun pada tataran pelaksanaan, berdasarkan hasil wawancara, distribusi penerima manfaat sebagai berikut :

a. Pemerintahan Nagari sebesar $30 \%$

b. Pemerintahan Adat sebesar $30 \%$

c. Kegiatan kepemudaan sebesar $40 \%$

Pembukaan Lubuk Larangan umumnya untuk membiayai kegiatan nagari, seperti pembangunan fisik nagari dan kegiatan kemasyarakatan. Antara lain pembiayaan kegiatan perayaan Hari Ulang Tahun Kemerdekaan, Upacara Adat 'Pulang Mamak' yaitu acara dimana semua anggota masyarakat nagari berkumpul termasuk yang sudah merantau yang diadakan bertepatan dengan Hari Raya Lebaran.

\section{Lubuk Larangan Sebagai Organisasi}

Pengelolaan lubuk larangan dilakukan oleh organisasi adat, yang terdiri dari ninik mamak². Ninik mamak ini dianggap sebagai pemilik nagari, mereka berperan besar secara adat dalam sebuah nagari. Mereka memegang keputusan-keputusan penting bagi kelangsungan sebuah nagari.
Lubuk larangan akan dibuka berdasarkan hasil kesepakatan antara Pokmaswas, Kerapatan Adat Nagari, pemuda dan tokoh agama dan dipimpin oleh Wali Nagari selaku pemimpin pemerintahan nagari. Pengawasan penegakan peraturan di Lubuk Larangan anak Nagari ini diserahkan kepada POKMASWAS (Kelompok Masyarakat Pengawas) yang didalamnya terdiri dari ninik mamak, tokoh agama, pemuda dan masyarakat.

Pelanggaran terhadap aturan dalam Lubuk Larangan diselesaikan melalui pengadilan adat. Pengadilan adat terdiri dari para ninik mamak yang memutuskan bersalah atau tidaknya dan sanksi atau denda yang akan dikenakan. Keputusan yang diambil merupakan hasil keputusan bersama dan jika terjadi pelanggaran maka pengadilan adat (ninik mamak) akan memanggil mamak $^{3}$ pelaku, saksi, dan wali nagari. Mamak merupakan lembaga yang mengurus kaum, menjaga martabat kaum sehingga peran mamak lebih besar dibandingkan peran ayah dalam sebuah keluarga. Hal inilah yang menyebabkan mamak yang harus bertanggungjawab jika terjadi pelanggaran termasuk terhadap aturan lubuk larangan.

Rapat untuk memutuskan sanksi melalui peradilan adat Kerapatan Adat Nagari yang dipimpin oleh wali nagari. Sanksi yang dijatuhkan kepada pelaku adalah dengan mengakui perbuatannya yang disiarkan langsung dari mesjid dan dikenakan denda berupa bahan bangunan seperti semen dan seng. Pelanggaran terhadap aturan pengelolaan lubuk larangan terakhir kali terjadi pada tahun 2008, seorang anak kecil memberi makan ikan yang didapatkannya dari lubuk larangan kepada hewan peliharaannya. Tidak lama kemudian anjing tersebut mati.

Peraturan terkait Lubuk Larangan saat ini juga sudah dijadikan Peraturan Nagari (PERNAG) yaitu Peraturan Nagari Sialang No. 02 Tahun 2011.

\section{Kontekstualisasi dan Dinamika Lubuk Larangan}

Pengetahuan lokal seperti hal nya budaya bukan sesuatu yang terberikan dan memiliki sifat yang tetap, melainkan bersifat dinamis karena manusia sebagai bagian dari masyarakat

${ }^{2}$ Ninik mamak adalah pemangku adat yang dipilih dari mamak dari setiap kaumnya. Mamak (paman) memegang peranan penting dalam kehidupan Masyarakat Minang yang menganut garis keturunan matrilineal.

${ }^{3}$ Mamak : saudara laki-laki tertua atau dituakan dari pihak ibu (saparuik) 
mengalami proses belajar sepanjang hidupnya. Kontak dengan pihak luar, interpretasi individu dapat menjadi penyebab terjadinya perubahan (Winarto \& Choesin, 2001). Hal ini juga terjadi dalam Lubuk Larangan. Saat ini penggunaan uduh mengalami pergeseran. Dianggap tidak sesuai dengan ajaran Islam, peng-uduh-an mengalami proses kontekstualisasi. Konteks yang ada saat ini, agama Islam mengakar kuat dalam kehidupan masyarakat Minang. Bagi Orang Minang, nilai agama serta organisasi keagamaan memegang peranan penting. Aturan adat yang berlaku mengakar pada aturan agama yang tergambar pada falsafah mereka yang berbunyi:

\section{"Adat basandi syarak, syarak basandi kitabullah, syarakmangatoadatmamakai" -Artinya adat berdasarkan syariat Islam, syariat berdasarkan AI-Quran"}

Falsafah di atas memperlihatkan adat istiadat yang menjadi sumber aturan kehidupan masyarakat Minangkabau, dibentuk dan dijalankan sesuai dengan aturan dan ajaran yang terdapat dalam Agama Islam dan berbagai ketentuan dalam agama Islam berdasarkan pada Al-Quran (Gani, 2006).

Berdasarkan falsafah di atas tersebut, maka uduh saat ini diganti dengan doa yang bernafaskan Islam yang kemudian termanifestasi dalam pembagian wilayah zona pemanfaatan lubuk larangan berdasarkan kepentingan organisasi keagamaan yang ada di nagari. Taatnya masyarakat nagari atas aturan lubuk larangan lebih berdasar pada kesadaran masyarakat akan fungsi sungai dan ketaatan terhadap ninik mamak (Kurniasari et al., 2012). Ninik mamak berperan besar dalam kehidupan Orang Minang, mereka dianggap sebagai pemilik nagari. Kepatuhan masyarakat terhadap ninik mamak, menjadikan ninik mamak sebagai tokoh sentral dalam membentuk perilaku kolektif (Kurniasari et al., 2012).

"ninik mamak adalah yang punya nagari, secara adat, sementara wali nagari adalah pelaksananya"
Dinamika pengelolaan Lubuk Larangan juga terjadiakibatadanya perubahan struktur pemerintah. Perubahan struktur pemerintahan menimbulkan perubahan struktur sosial, politik, nilai serta aturan. Menurut Franz von Benda-Beckman, Nagari merupakan pemerintahan terkecil di Minangkabau sejak jaman pra-kolonial. Nagari adalah kesatuan masyarakat hukum adat yang dipimpin oleh Wali Nagari yang dipilih berdasarkan kesepakatan bersama. Naim (1990) menyatakan bahwa Nagari tidak hanya merujuk pada teritorial, darimana seseorang berasal, namun juga menangandung makna dari keluarga atau keturunan siapa seseorang itu berasal (genealogis). Ini yang membedakan nagari dengan desa yang ada di Jawa (Noer, 2004). Nagari tidak hanya merupakan wilayah kediaman (Bakarong Bakampuang) namun juga kesatuan hukum adat dimana di dalam sebuah nagari juga harus memenuhi prinsip Basuku Banagari dimana warga nagari minimal terdiri dari empat suku yang masing-masing suku dipimpin oleh Penghulu (Astuti et al., 2009).

Dalam sistem pemerintahan tradisional, struktur pemerintahan nagari terdiri dari Wali nagari dan Kerapatan Adat Nagari(KAN) ${ }^{4}$. Pemilihan wali nagari sebagai pemimpin nagari dilakukan secara langsung oleh komunitas adat dan kelompok genealogisnya. Artinya, yang menjadi wali nagari adalah penduduk asli nagari (bukan pendatang). Jalannya Pemerintahan nagari tidak hanya melibatkan wali nagari sebagai pemimpin nagari, namun juga memperhatikan kepemimpinan adat yang terdiri dari Ninik Mamak, atau yang biasa disebut dengan Penghulu, yang bertugas mengurusi adat istiadat, Alim Ulama yang bertugas mengurusi masalah keagamaan dan Cadiak Pandai (Cerdik Pandai) yang bertugas dalam hal peraturan, atau perundang-undangan ${ }^{5}$. Sistem kepemimpinan adat ini mewarnai sistem pengelolaan Lubuk Larangan. Kala ini, pengelolaan lubuk larangan, berada di bawah pemerintahan adat, sebab lubuk larangan termasuk ke dalam hak ulayat (Akmal, 2008). Pembentukan, pengelolaan, serta pengawasan Lubuk Larangan diatur oleh pemerintahan adat melalui organisasi Kerapatan Adat Nagari.

\footnotetext{
${ }^{4}$ Kerapatan Adat Nagari menurut Perda Propinsi Sumatera Barat Nomor 16 tahun 2008 adalah lembaga perwakilan permusyawaratan dan permufakatan tertinggi nagari yang telah ada dan diwarisi secara turun temurun sepanjang adat di tengah-tengah masyarakat di Sumatera Barat, KAN merupakan himpunan ninik mamak dalam sebuah nagari

${ }^{5}$ Ketiganya memegang peranan penting dalam sistem pemerintahan nagari, mereka dinamakan tungku tigo sajarangan yang diatur dalam Perda Nomor 134 Tahun 1978. Falsafah ini berasal dari istilah didalam kegiatan memasak, yaitu tiga batu yang dibentuk menyerupai segitiga difungsikan sebagai tungku yang digunakan untuk memasak (Gani,2005 ).
} 
Masa selanjutnya adalah masa berlakunya sistem pemerintahan desa sebagai pemerintahan daerah terendah, hasil adopsi dari sistem pemerintahan di Jawa sesuai dengan UU No.5 Tahun 1979. Saat ini pemilihan Kepala desa ditentukan langsung oleh pejabat di atasnya (Camat). Pemerintah membentuk Lembaga Musyawarah Daerah (LMD) dan Lembaga Ketahanan Masyarakat Desa (LKMD) yang di dalamnya terdapat unsur ninik mamak. Namun fungsi pengawasan terhadap pemerintah tidak dapat dilakukan oleh kedua lembaga ini sebab keduanya dipimpin oleh Kepala Desa (Astuti et al., 2009). Tidak hanya masalah kepemimpinan, masalah wilayah teritorial pun menjadi berubah. Sistem pemerintahan desa membuat lembaga adat yang ada di pemerintahan nagari sebelumnya kehilangan peran. Masa ini, tidak ada yang secara langsung mengelola Lubuk Larangan.

\section{Saat ini lubuk larangan hanya pakai uduh saja...siapa yang berani ambil ikan, kembung perutnya...ngga ada yang kelola masa ini...}

Masa ketiga adalah masa kembali kepada sistem pemerintahan nagari sebagai sistem pemerintahan daerah terendah. Masa diberlakukannya kembali sistem pemerintahan nagari, seiring dengan berlakunya Undang-Undang Nomor 22 Tahun 1999 tentang pemerintahan daerah. Wali Nagari menjadi pemimpin dalam pemerintahan sebuah nagari dengan sistem pemilihan yang terbuka, namun tetap harus berdasarkan perda provinsi. Melalui Peraturan Daerah Nomor 16 Tahun 2008, Kerapatan Adat Nagari (KAN) kembali difungsikan dalam menjalankan pemerintahan sebuah nagari yang salah satunya adalah mengurusi hak ulayat nagari, termasuk di dalamnya lubuk larangan. Nagari Sialang memiliki 8 ninik mamak yang mewakili 8 suku yang mendiami Nagari Sialang. Para ninik mamak inilah yang duduk dalam lembaga Kerapatan Adat Nagari. Pengelolaan Lubuk Larangan diserahkan kepada POKMASWAS (kelompok masyarakat pengawas), sementara pemerintah adat (KAN) dan pemerintah daerah menjalankan fungsi pengawasan.

Pengetahuan lokal merupakan faktor potensial dalam menunjang keberlanjutan pengelolaan sumber daya. Namun pengetahuan lokal ini harus terus diperbaharui dan diperkaya karena memiliki kekurangan dalam membantu para pendukungnya untuk memahami dinamika lingkungan hidup yang kompleks dan kondisi ketidakpastian yang besar. Pengayaan pengetahuan mengenai ekosistem disertai pengembangan institusi sosial dapat membantu mewujudkan pengelolaan sumber daya yang bekelanjutan (Winarto \& Choesin, 2001).

\section{KESIMPULAN DAN IMPLIKASI KEBIJAKAN}

\section{Kesimpulan}

Pengetahuan lokal yang terwujud dalam praktek konservasi sumber daya menunjukkan bahwa masyarakat lokal memiliki pengetahuan dalam pengelolaan sumber daya dan kontrol terhadap pemanfaatan sumber daya yang ada. Hal ini karena secara langsung merekalah yang memiliki kepentingan terhadap sumber daya tersebut.

Pengetahuan lokal ini bersifat dinamis. Dinamika pengetahuan lokal masyarakat dalam hal pengelolaan sumber daya alam perikanan menggambarkan bahwa kebudayaan bersifat dinamis dan fungsional dalam kehidupan masyarakat.

Lubuk Larangan merupakan salah satu bentuk pengelolaan sumber daya yang berasal dari pengetahuan lokal masyarakat Minang di Sumatera Barat. Lubuk Larangan selain memiliki fungsi ekologi juga memiliki fungsi ekonomi, sosial dan budaya. Sebagai salah bentuk pengetahuan lokal, Lubuk larangan yang dalam perjalanannya mengalami dinamika. Dinamika pada Lubuk larangan terjadi karena perubahan sumber daya, agama dan sistem pemerintahan.

\section{Implikasi Kebijakan}

Praktek pengelolaan sumber daya seperti Lubuk Larangan ini dapat menjadi bahan dalam pengembangan pengelolaan sumber daya di Indonesia. Yang perlu diperhatikan, pertama, penyempurnaan bentuk pengelolaan Lubuk Larangan ataupun praktek pengelolaan sumber daya lainnya sehingga tidak terjebak dalam romantismenya saja. Kedua, pengelolaan sumber daya yang ada di suatu masyarakat tidak serta merta dapat diterapkan di masyarakat lain. Penyempurnaan bentuk pengelolaan sumber daya dengan melalui pengayaan dan pembaharuan pengetahuan lokal perlu dilakukan tanpa melupakan kedinamisan sebuah pengetahuan sehingga tercipta pengelolaan sumber daya yang bekelanjutan. Selain itu perlu dipertimbangkan peran antropologi dalam menentukan kebijakan pemerintah terutama 
terkait dengan otonomi daerah yang di dalamnya mengatur hal pengelolaan sumber daya.

\section{DAFTAR PUSTAKA}

Akmal. 2008. Perlindungan Hak Masyarakat Hukum Adat di Sumatera Barat. Jurnal Demokrasi, Volume 7 (1): 1-16.

Alam, B. 1998. Globalisasi dan Perubahan Budaya: Perspektif Teori kebudayaan. Jurnal Antropologi Indonesia No. 54: 1 - 11.

Anonimous, 2012. Peraturan Daerah Provinsi Sumatera Barat Nomor 4 Tahun 2012 Tentang Pengelolaan dan Perlindungan Sumberdaya Ikan. http://padangtoday. com/info/wp-content/uploads/2013/09/ perda-pengelolaa-perlindungan-sumber daya-ikan.pdf (Diakses pada 21 Januari 2014).

Astuti, N.B., L.M. Kolopaking \& N.K. Pandjaitan. 2009. Dilema Dalam Transformasi Desa Ke Nagari: Studi Kasus di Kenagarian IV Koto Palembayan, Provinsi Sumatera Barat. Jurnal Sodality: Jurnal Transdisiplin Sosiologi, Komunikasi, dan Ekologi Manusia. Volume 3 (2):167 - 186.

Gani, R. 2005. "Tungku Tigo Sajarangan": Analisis Pola Komunikasi Kelompok dalam Interaksi Pemimpin Pemerintahan di Sumatera Barat. Jurnal Mediator Volume 7 (2): 243 - 258.

Kasniyah, N. 2005. Antropologi Pasca "Pembangunan": Dimensi Antropologi Terapan. Humaniora Volume 17 (3): 293 300.

Kurniasari, N., M. Yulisti \& C. Yuliaty. 2012. Lubuk dan Kearifan Lokal Masyarakat Adat. Badan Penelitian dan Pengembangan Kelautan dan Perikanan dan Indonesian Marine and Fisheries Socio-Economics Research Network. Jakarta. 107 hal.

Lubis, Z.B. 2005. Menumbuhkan (Kembali) Kearifan Lokal dalam Pengelolaan Sumber daya Alam di Tapanuli Selatan. Jurnal Antropologi Indonesia Volume 29 (3): 239 - 254.

Lowe, C. 2006. Kajian Antropologi Tentang Globalisasi: Catatan Tentang Studi- Studi keterkaitan Dunia. Jurnal Antropologi Indonesia Volume 30 (3): 263 - 272.

Maskur. 2002. Program Pelestarian Plasma Nutfah Ikan-Ikan Perairan Umum. Jurnal Akuakultur Indonesia Volume 1(3): 139-144.
Moleong, L.J. 2006. Metodologi Penelitian Kualitatif, hal 5 - 6. Bandung: PT. Remaja Rosdakarya Offset.

Naim, M. 1990. Nagari Versus Desa: Sebuah Kerancuan Struktural. dalam Mohammad Hasbi, et all (Eds). Nagari, Desa dan Pembangunan Pedesaan di Sumatera Barat. Padang: Yayasan Genta Budaya.

Noer, M. 2004. Pembangunan Berbasis Kelembagaan Adat: Sebuah Alternatif Pembelajaran dari Kasus Kinerja Kelembagaan Nagari dalam Perencanaan Wilayah di Propinsi Sumatera Barat. Jurnal Mimbar Volume XXII (2) April-Juni: 234 257.

Priyatna, F.N. 2003. Model Pengelolaan Sumber daya Perikanan Berdasarkan Karakteristik Sosial Ekonomi Masyarakat Nelayan di Desa Karangjaladri, Parigi, Jawa Barat: Tinjauan Sosiologi-Antropologi. Skripsi.(Tidak dipublikasikan) Program Studi Manajemen Bisnis dan Ekonomi Perikanan Kelautan. Jurusan Sosial Ekonomi Perikanan dan Kelautan. Fakultas Perikanan dan IImu Kelautan. Institut Pertanian Bogor. 114 hal.

Solihin, A. \& A. Satria. 2007. Hak Ulayat Laut di Era Otonomi Daerah sebagai Solusi Pengelolaan Perikanan Berlanjut : Kasus Awig- Awig di Lombok Barat. Sodality, Jurnal Transdisiplin Sosiologi, Komunikasi dan Ekologi Manusia, Volume 1 (1): 67-86.

Suhana. 2009. Pengakuan Keberadaan Kearifan Lokal Lubuk Larangan Indarung Kabupaten Kuantan Senggigi dalam Pengelolaan Lingkungan Hidup . http://pk2pm. wordpress.com/2009/12/13/pengakuan-keberadaan-kearifan-lokal-lubuk-larangan-indarung (Diakses 17 Juli 2012).

Syahyuti. 2010. Konsep dan Strategi Pendekatan Kultural dalam Pembangunan Pertanian: Studi Kasus Pembangunan Pertanian di Thailand. http://www.ut.ac.id/html/suplemen/ luht4210/Pendekatankultural_pembangunanpertanian.pdf (Diakses pada 12 Agustus 2013).

Tambunan, R. 2008. Perilaku Konservasi pada Masyarakat Tradisional. Jurnal Harmoni Sosial Vol. 2 (2): 83 - 87.

Tan, M.G. 1994. Masalah Perencanaan Penelitian In Koentjaraningrat (ed). Metode-Metode Penelitian Masyarakat, hal 24 - 60. Jakarta: PT. Gramedia Pustaka Utama. 
Winarto, Y.T \& E.M. Choesin. 2001. Pengayaan pengetahuan Lokal, Pembangunan Pranata Sosial : Pengelolaan Sumber daya Alam dalam Kemitraan. Jurnal Antropologi Indonesia Volume 25 (64): 91 - 106.
Yuliaty, C., N. Kurniasari \& M.Yulisti. 2012. Lubuk Larangan Anak Nagari: Studi Bentuk Kearifan Lokal di Kabupaten Lima Puluh Kota. Prosiding Konferensi Nasional (KONAS) VIII Pengelolaan Sumber daya Pesisir,Laut, dan Pulau-Pulau Kecil, Mataram, 22-24 Oktober 2012, ISBN : 978-979-3556-91-8. 